\title{
Ecological Devastation in Lake Victoria: Part B: Plankton and Fish Communities
}

\author{
Moshe Gophen \\ Migal-Scientific Research Institute, Kiryat Shemone, Israel \\ Email: Gophen@Migal.org.il
}

Received 8 June 2015; accepted 12 July 2015; published 15 July 2015

Copyright (C) 2015 by author and Scientific Research Publishing Inc.

This work is licensed under the Creative Commons Attribution International License (CC BY).

http://creativecommons.org/licenses/by/4.0/

\section{(c) (i) Open Access}

\begin{abstract}
A few specimens of the exotic fish, Nile Perch, (Lates niloticus, Linnaeus 1758) were transferred into Lake Victoria in early 1950's. In early 1980's this fish occupied the Lake Victoria ecosystem eliminating the local endemic Haplochromines (app. 400 species). As a result of this change, together with intensification of pollution constrains from the catchment and dust deposition the ecology of Victoria's ecosystem was modified: cyanobacteria replaced diatoms, anoxia enhanced, secchi depth became shallower, euphotic zone became thinner, fishery enhanced fully comprised of Nile Perch and Rastrineobola. The ecological significances are discussed and future propositions are presented.
\end{abstract}

\section{Keywords}

Lake Victoria, Nile Perch, Ecological Changes, Fish, Plankton

\section{Introduction}

Lake Victoria, the second (excl. Caspian Sea) largest lake in the world by surface area $\left(68,800 \mathrm{~km}^{2}\right.$ ) and $7^{\text {th }}$ by Volume $\left(2800 \mathrm{~km}^{3}\right)$ has undergone fundamental changes of its limnological structure. The lake is located at an altitude of $1134 \mathrm{~m}$ above Mean Sea Level and stretched between latitudes of $0^{\circ} 20^{\prime} \mathrm{N}-3^{\circ} 0^{\prime} \mathrm{S}$ and $31^{\circ} 39^{\prime} \mathrm{W}$ $34^{\circ} 53^{\prime} \mathrm{E}$. Limnological changes include not only internal modifications enhanced by the Nile Perch invasion [1] but also by external anthropogenic activities in the catchment resulted in input of $20 \mathrm{~kg} / \mathrm{km}^{2} /$ year of total phosphorus and $400 \mathrm{~kg} / \mathrm{km}^{2} /$ year, in addition to atmospheric contaminated dust deposition [2] [3] and as a consequence Lake Victoria clearly exhibit symptoms of eutrophication (Table 1). The lake and the drainage Basin territories are shared between three countries (Figure 1): Kenya, Tanzania and Uganda. The ratio between Cat- 


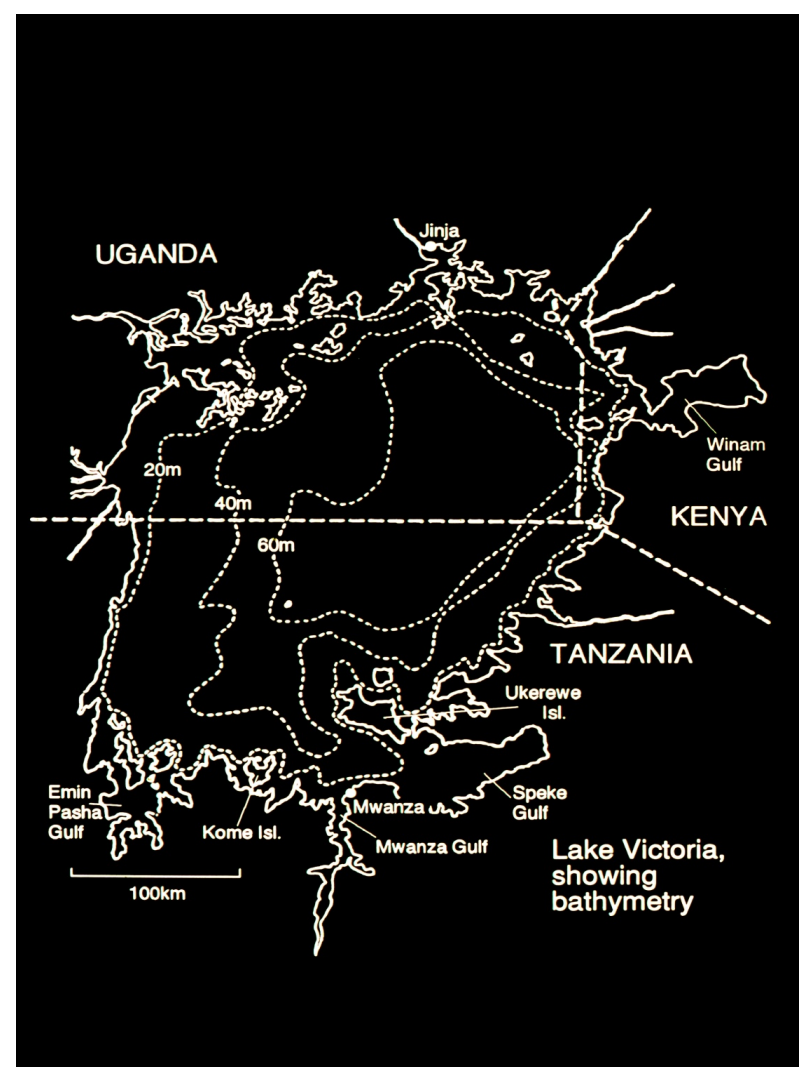

Figure 1. Bathimetrical-Geographical Map of Lake Victoria.

Table 1. Annual ranges of nutrients (mg/l, $\mu \mathrm{g} / \mathrm{l})$, Primary Production (PP) (mg DO/m³) and Chlorophyll Concentration ( $\mu \mathrm{g} / \mathrm{l})$ in Lake Victoria during 1966-1990 [4]-[9].

\begin{tabular}{ccccccc}
\hline Parameter & 1966 & 1977 & 1979 & 1984 & 1989 & 1990 \\
\hline $\mathrm{PO}_{4}(\mu \mathrm{g} / \mathrm{l})$ & $7-120$ & $1-122$ & & $2-75$ & $4.0-37$ & $1-19$ \\
$\mathrm{NO}_{3}(\mu \mathrm{g} / \mathrm{l})$ & $10-112$ & $0.5-122$ & $0.16-0.18$ & $21-237$ & $0.1-513$ & $1-30$ \\
$\mathrm{SO}_{4}(\mathrm{mg} / \mathrm{l})$ & $0.4-4.0$ & & & $0.1-5.0$ & & $0.06-0.72$ \\
$\mathrm{SiO}_{2}(\mathrm{mg} / \mathrm{l})$ & $4-8$ & $0.2-3$ & $2-7.9$ & $0.1-7.6$ & & $100-1400$ \\
$\mathrm{PP}\left(\mathrm{mg} \mathrm{DO} / \mathrm{m}^{3}\right)$ & $100-130$ & & $400-600$ & & $180-600$ & $35.8-115.2$ \\
$\begin{array}{c}\mathrm{Chlorophyll} \\
(\mu \mathrm{g} / \mathrm{l})\end{array}$ & $0.5-22.3$ & $2.1-8.5$ & & $1.8-23.5$ & $8-120$ & \\
\hline
\end{tabular}

chment area and lake Volume is $11.7 \mathrm{~m}^{3} / \mathrm{m}^{2}$ i.e. each $\mathrm{m}^{3}$ of the lake accept nutrients from $11.7 \mathrm{~m}^{2}$ of the catchment. The D number for Lake Victoria is 3.7. Those two indicators exhibit high potential of nutrient supply from the catchment (Table 1). The major inflow rivers are Kagera and Nzoia (Tanzanian part of the lake), the only outflow is through the White Nile river, outlet located North, nearby Jinga, Uganda.

Phytoplankton research in Lake Victoria started in 1898 when expeditions were carried out to collect net hauling samples, therefore, information until the 1960's is limited to algal taxonomy. Talling [4] [5] was the first who studied long term cycle of community composition, quantitative abundance, population dynamics and vertical distribution and later on Kenyan and other scientists continued [6] [7] [9]. The Zooplankton of Lake Victoria was studied by Rzoska and others [10]-[14]. The research of fish biology and fisheries management in lake Victoria was enhanced by local and external scientists, resulted by the Nile Perch Invasion [15]-[18]. The objective of our study was to initiate an international effort to collect data about the ecological changes in Lake Victoria caused by the Nile Perch invasion and to establish a Data Base for future investigations. Our studies and 
consequently the Lake Victoria Data Base (LVDB) information were previously summarized in technical reports which are publicize here as a scientific paper.

\section{Material and Methods}

\subsection{Sampling Stations (1989-1992)}

Eighteen sampling stations (Figure 2) were monthly monitored for physico-chemical parameters (DO, $\mathrm{pH}$ and Temperature), and plankton: 8 stations in Wynam Gulf (numbered: 1,2,3,17, 30, 31, 36, 37), 4 Stations at the transition zone between Wynam (Kavirondo) Gulf and the open waters (offshore) (numbered: 5, 6, 7, 8,), 1 (numbered: 34) station in the Rusinga Channel, and 5 stations in offshore zone (numbered: 32, 33, 55, 100, 103).

\subsection{Zooplankton Sampling}

Samples were collected from discrete depths and 3 liters were sieved through $100 \mathrm{~m}$ mesh size net on board, and all organisms were flushed into bottles (final volume of 30-50 ml) and $5 \mathrm{ml}$ formalin 10\% were added. Counts were carried out in the Kinneret Limnological Laboratory (Israel) under Wild M5 stereoscope.

\subsection{Phytoplankton Sampling}

Original sampled waters $(125 \mathrm{ml})$ were placed in brown bottles and a few drops of Lugol were added. Counts were carried out in Kinneret Limnological Laboratory and IOLR-Haifa Institute by Utermol's sedimentation method in $10 \mathrm{ml}$ chambers, under Inverted Microscope (Zeise M20) and counts were done.

\subsection{Fisheries}

Information on fishery in Lake Victoria (1968-1991) was supported by Kenya Marine and Fisheries Research Institute. Statistical evaluation of the data was evaluated by Simple Linear Regressions between annual landings (dependent variable) and years (independent variable), $\mathrm{r}^{2}$ (correlation coefficient) which indicates the strength of the association between the two variables and $\mathrm{p}$ (probability) values are given.

\subsection{Fish Gut Content, Body Condition \& Index of Satiation (IOS)}

The Tilapias, T. niloticus, $T$. variailis, $T$. zillii, $T$. niloticus specimens were collected from fishermen yields, total length and weight were measured, then the viscera (Stomach \& intestine) was removed individually and weighed, placed in plastic bottles and preserved by $5 \mathrm{ml}$ 10\% formalin. Samples were taken to Kinneret Limno-

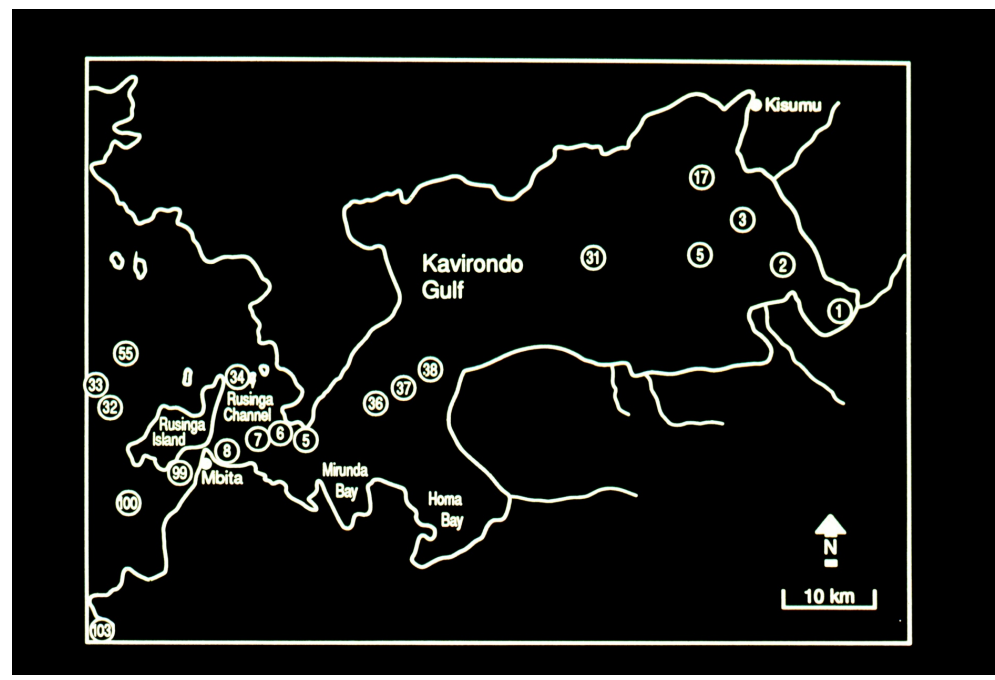

Figure 2. The Kenyan Part of Lake Victoria Kavirondo, (Wynam) Gulf Sampling Stations are numbered. 
logical Laboratory for second weight measurement, gut content was squeezed and food items analysis under both Wild M5 Binocular and Light Microscope (M20) was carried out. Index of Satiation (IOS) was calculated as follows:

Viscera (stomach-intestine) Weight (g) - V.

Body Weight (g)-B.

$(\mathrm{V} / \mathrm{B}) \times 100=$ IOS.

\subsection{Zooplankton Removal by Fish: Feeding Experiments}

Living specimens of Tilapias, (T. leucostictis, T. variabilis, T. zillii, T. niloticus T. esculentus) were collected alive from beach seine catches and immediately transferred into Aquaria containing 60 - 70 filtered (63 $\mu$ mesh size) lake water in duplicates (two per species) and fishless aquaria for the determination of zooplankton natural mortality. Freshly collected ( $100 \mu$ sieving) live zooplankton were added in similar aliquots to the aquaria. Water samples were taken from the tanks at initial (zero) time and 3 times with intervals of 30 and 40 minutes and last sample was taken after 1 hour. The samples were taken by plastic pipe ( $2.5 \mathrm{~cm}$ diameter) closed by rubber cup placed randomly on the bottom of the aquaria. Samples were filtered through $63 \mu$ mesh size net and all zooplankton organisms were counted under M5 Wild Binocular. Zooplankton mortality was subtracted from counted organisms and \% removal was evaluated. Seven trials were carried out.

Fishes body weight and number of trials were as follows:

T. zillii, 2 fishes, 1 trial TL: 20, $12 \mathrm{~cm}$.

T. niloticus, 4 fishes, 2 trials, TL: 13, 12.6, $14,12.3 \mathrm{~cm}$.

T. variabilis, 21 fishes, 4 trials, TL: $8.1-22.7 \mathrm{~cm}$.

T. leucostictus, 4 fishes, 1 trial, TL: $8.1-14.0 \mathrm{~cm}$.

The Aquaria were slightly aerated.

\section{Results}

\subsection{Nutrients}

Samples were collected in stations numbered (Figure 2): 1, 6, 17, 31, 32, 33, 34, 36, 37, 38, 100, 103 at depths of (m): $0,1,2,3,5,9,11,15,20,23,25,30,35,39,40$, and 42 with respect to the actual depth. The following parameters were measured: Total Nitrogen (TN), Ammonium $\left(\mathrm{NH}_{4}\right)$, Nitrate $\left(\mathrm{NO}_{3}\right)$, Total Phosphorus (TP) and Ortho-Phospate (OP) (Methods are given in [3]). The mass (W/W) TN/TP ratio was calculated. Results are given in Table 2.

Results given in Table 2 indicates the followings: percentage of OP from TP is similar throughout the centire water column: $35 \%$ and $40 \%$ in the upper and lower part respectively; Similarity of \% of Inorganic Nitrogen $\left(\mathrm{NH}_{4}+\mathrm{NO}_{3} ; \mathrm{NO}_{2}\right.$ is negligible) from TN was also indicated within the entire water column; Particulate Organic Nitrogen comprised $>90 \%$ of TN; Prominent increase of TP in lower part of the water column, therefore the TN/TP W/W mass ratio decline in deep waters. These chemical conditions of low TN/TP ratio are favored by Cyanobacteria.

\subsection{Phytoplankton}

Cyanobacteria were prominently dominant in all samples. The following genera and partly species were defined:

Table 2. Averaged (SD) concentrations (ppm) of chemical parameters measured in all stations and combined into 2 water layers: $<10 \mathrm{~m}$ and $>10 \mathrm{~m}$ depths [3].

\begin{tabular}{|c|c|c|c|c|c|c|}
\hline $\begin{array}{l}\text { Depth } \\
\text { Layer }\end{array}$ & $\begin{array}{c}\mathrm{TN} \\
(\mathrm{ppm})\end{array}$ & $\begin{array}{c}\mathrm{NH}_{4} \\
(\mathrm{ppm})\end{array}$ & $\begin{array}{c}\mathrm{NO}_{3} \\
(\mathrm{ppm})\end{array}$ & $\begin{array}{c}\mathrm{TP} \\
(\mathrm{ppm})\end{array}$ & $\begin{array}{c}\mathrm{OP} \\
(\mathrm{ppm})\end{array}$ & $\mathrm{TN} / \mathrm{TP}$ \\
\hline$<10 \mathrm{~m}$ & $\begin{array}{c}1.136 \\
(0.651)\end{array}$ & $\begin{array}{c}0.073 \\
(0.073)\end{array}$ & $\begin{array}{c}0.024 \\
(0.021)\end{array}$ & $\begin{array}{c}0.075 \\
(0.024)\end{array}$ & $\begin{array}{c}0.026 \\
(0.011)\end{array}$ & $\begin{array}{l}15.6 \\
(7.4)\end{array}$ \\
\hline$>10 \mathrm{~m}$ & $\begin{array}{c}1.185 \\
(1.363)\end{array}$ & $\begin{array}{c}0.104 \\
(0.096)\end{array}$ & $\begin{array}{c}0.026 \\
(0.020)\end{array}$ & $\begin{array}{c}0.134 \\
(0.198)\end{array}$ & $\begin{array}{c}0.054 \\
(0.084)\end{array}$ & $\begin{array}{l}10.6 \\
(7.3)\end{array}$ \\
\hline
\end{tabular}




\subsubsection{Cyanobacteria}

Merismopedia, Lyngbia circumcreta, Aphanocapsa delicatissima, Microcystis, Anabaena flos aqua, Chroococcus, Cylindrospermopsis.

\subsubsection{Bacillariophyta (Diatoms) Chlorophyta, Pyrrhophyta}

Nvicula rynchocephala, Synedra cunningtonii, Melosira (Aulacoseira) granulate var. angustissima, Melosira (Aulacoseira) nyassensis var. Victoria, Nitzschia acicularis, Chlorophyta: Scenedesmus, Chlamydomonas, Scenedesmus quadricauda, Pediastrum, Cosmarium, Oocystis solitario, Pyrrhophyta: Cryptomonas, Glenodinium pulvioulus.

\subsubsection{Algal Density}

Densities of Cyanobacteria varied within the range of maximum of 4000/ml and minima between 200 $1000 / \mathrm{ml}$.

Dominant algae during 1966-1979 were Diatoms and later-Cyanobacteria.

Results of algal densities measured during 1989-1990, in Wynam Gulf (Kavirondo) at 0, 1, 5, 7, and $10 \mathrm{~m}$ depths;, Rusinga Channel at 2, 3, 5, and 20 m depths; and in the deep offshore open waters stations at 0, 1, 1.5, 5, 16, 1nd 20 mdepths; were (No. per ml).

\subsubsection{Wynam Gulf}

Aphanocapsa-1200 - 3500; Lyngbia-300 - 3900; Merismopedia-200 - 1000; Microcystis—400 - 1200; Anabaena-300 - 1000; Chroococcus—200 - 900; Coenobial Cyanophytes—>3000; Cylindrospermopsis—500; Melosira (Aulacoseira)—600 - 1400; Synedra-200 - 3300; Navicula-300; Rhodomonas-300; Chlamidomonas-300; Scenedesmus-200 - 400; Cryptomonas-300 - 400.

\subsubsection{Rusinga Channel}

Aphanocapsa-1600; Lyngbia-900 - 17,000; Microcystis—600; Chroococcus-400; Cylindrospermopsis600 - 4100; Synedra-2400 - 4900; Rhodomonas—500; Cryptomonas—400.

\subsubsection{Offshore}

Lyngbia-2100 - >10,000; Cylindrospermopsis—2700 - >4000; Synedra-2000 - >3000. Algal species diversity is much higher in the shallow water of Wynam Gulf and the dominance of Cyanobacteria is prominent.

\subsection{Zooplankton}

The Following species were identified in samples collected during 1989-1990:

\subsubsection{Copepoda}

Thermocyclops neglectus, Thermocyclops hyalinus, Mesocyclops leuckarti, Microcyclops minutus.

\subsubsection{Calanoida}

Thropodiaptomus neumanii.

\subsubsection{Cladocera}

Diaphanosoma excisum, Ceriodaphnia rigaudii, Daphnia longispina, Moina macrura, Bosmina longirostris, Chydorus sphaericus.

\subsubsection{Rotifera}

Brachionus caudatus, Brachionus calyciflorus, Keratella tropica, Polyarthra remata, Filinia longispina, Asplanchna brightwelli, Collotheca sp., Trichocerac sp., Ascomorpha sp. Samples for zooplankton density counts (excluding Caridina nilotica) were collected in all stations during 1989-1990; The dominant (most common) group was Cyclopoida presented in all stations and depths from surface down to bottom layers (40 meters in offshore stations). Densities of cyclopoids and calanoids varied between 3 - 88 and 0 - 56 per litre respectively. In all zooplankton samples cladocerans were found only in 27 and rotifers in 26 of them. Densities of cladocerans and roti- 
fers varied between (Maximum-Minimum) 1 - 28 and 1 - 56 per litre for cladocerans and rotifers respectively.

\subsection{Zooplankton Consumption}

\section{Feeding Experiments}

Consumption of zooplankters by Tilapias as concluded from feeding experiments is given in Table 3 . Results presented in Table 3 indicates that the major source of zooplankton prey by 4 Tilapia species from Lake Victoria as concluded from 7 trials of feeding experiments are small organisms of young stages of cyclopoid and rotifers.

\subsection{Gut content Analysis}

Results in Table 4 indicate that major trophic source for the Haplochromines that were captured in Mwamza Gulf are suspended particles of detritus, phytoplankton, and zooplankton probably collected by filtration.

Results in Table 5 indicate that Tilapias collected in the Kenyan open waters collect their food mostly in bottom sediments.

\section{Body Condition and Food Composition of Sampled Tilapias}

For the study of body condition and food composition of Tilapias we sampled specimens in Wynam Gulf Stations $(6,34,36)$ and offshore (100) during January February and March. Number of analyzed specimens was:

Tilapia variabilis (TV)—69.

Tilapia zillii (TZ)-22.

Tilapia nilotica $(\mathrm{TN})-33$.

Tilapia esculentus (TE)-13.

Tilapia leucostictus (TL)-13.

Table 3. Zooplankton Predation by Tilapias from Lake Victoria: zooplankters which were removed from the water in feeding experiments at a level of $>50 \%$ are listed.

\begin{tabular}{ccc}
\hline Experiment \# & Fish Species & Zooplankters Removed \\
\hline 1 & T. niloticus & Cyclopoid Nauplii small rotifers \\
2 & T. zillii & Cyclopoid Nauplii\&adults small \& Large rotifers \\
3 & T. variabilis & Cyclopoid Nauplii, small rotifers \\
3a & T. variabilis & Adult Cyclopoids \\
3b & T. variabilis & Cyclopoid Nauplii \& Copepodites \\
4 & T. leucostictus & Cyclopoid Nauplii, small rotifers \\
5 & T. niloticus & Cyclopoid Nauplii Copepodites, small rotifers
\end{tabular}

Table 4. Trophic composition of Haplochromine fishes in Mwanza Gulf (Tanzania), Lake Victoria.

\begin{tabular}{|c|c|c|}
\hline Trophic Element & \% by number & Estimated \% by weight \\
\hline Detritivores/Planktivores & 38 & 31 \\
\hline Phytoplanktivores & 22 & 18 \\
\hline Zooplanktivores & 30 & 25 \\
\hline Insectivores & 5 & 15 \\
\hline Molluscivores & 1 & 3 \\
\hline Piscivores & 2 & 5 \\
\hline Caridinia Predatores & 1 & 2 \\
\hline Other & 1 & 1 \\
\hline
\end{tabular}


Total and Standard lengths of all Tilapias ranged between 10 - $55 \mathrm{~cm}$ and 8 - $50 \mathrm{~cm}$ respectively. The Body Weight of all Tilapias ranged between $100-600 \mathrm{~g}$, and the Viscera (stomach and intestine) weights range was - 0.2 - 22.0 g; Index of Satiation (IOS) was calculated (see Methods) for individual specimen (Table 6).

\subsection{Index of Satiation (IOS)}

Results in Table 6 indicated similar intensity of food ingestion by the five species of Tilapias during 1 - 3 winter months.

Food Composition of three species of Tilapia (T. nilotica, T. variabilis, T. zillii) was analyzed on 124 specimens which were sampled during January-March 1989, in Wynam Gulf at Stations 6, 34, 36 and offshore zone-Stn.100. Their gut contents were removed individually and analyzed under both Dissecting Microscope (M5 Wild) and Light Microscope (Dialux 20). Food items were counted and their biomass was calculated as measured bio-volume converted to weight (specific gravity $=1.0$ ) and the summary is given in Table 6 \& Table 7.

Results in Table 7 indicate that the 57\%, 68\% and 55\% of the food items consumed by TZ, TV and TN respectively is collected from the bottom whilst the source of the rest is probably planktonic. It should be considered that video filming in deep anoxic waters at stations 100, 32 and 34 (results are not presented) indicated the existence of high densities of the Atyid Decapod, Caridina nilotica there. Therefore, C. nilotica might be defined as partial "bottom layer" inhabitant.

\section{Discussion}

The phytoplankton as analyzed in this study is characterized by high densities of coccoids accompanied by small filaments of Cyanophytes (Lyngbia). Diatoms were presented by Nitzchia and Melosira (Aulacoisera) and the chlorophytes by Chlorococcales and desmids. Dinophytes and Cryptophytes were rarely observed. The densities of zooplankton were mostly low and their body size small. The most abundant group was cyclopoid copepods. The results of feeding experiments were unpredicted: most of the organisms which were removed from the water by the fish were free swimming small body zooplankton and gut content analysis of specimens collected in the lake indicated deep layer and bottom inhabited organisms. It is therefore concluded that as a result of the Nile Perch invasion Tilapias were pushed by the Perch downward to find a refuge space where they can be better protected. The bottom habitat was utilized by Tilapias as a refuge and therefore bottom organisms were preyed and indicated in the Tilapias gut contents.

Data presented in Table 1, Table 2 \& Table 8 and Figure 3 summarize the ecological changes induced by the Nile Perch invasion and environmental pollution: Elimination of the native fish species (Haplochromines, Tilapias) and prominent increase of the exotic Nile Perch and the pelagic small size native Rastrineobola. The food-web structure was prominently modified: Before 1980 (Figure 3): Optimal balanced food-web, strong

Table 5. Gut Content analysis of Tilapias [15] fished in the Kenyan offshore waters of Lake Victoria. \% of specimens contained $>50 \%$ of their gut content biomass the indicated food form.

\begin{tabular}{cccc}
\hline Food Component & T. niloticus $(\mathrm{n}=70)$ & T. variabilis $(\mathrm{n}=46)$ & T. zillii $(\mathrm{n}=24)$ \\
\hline $\begin{array}{c}\text { Benthic, Deep Water } \\
\text { Mud, Sand }\end{array}$ & $58 \%$ & $74 \%$ & $87 \%$ \\
\hline
\end{tabular}

Table 6. Averages (SD) of Maxima and Minima of IOS values of Tilapias: T. variabilis (TV), T. zillii (TZ), T. nilotica (TN), T. esculentus (TE), T. leucostictus (TL), sampled during January-March 1989, in Wynam Gulf at Stations 6, 34, 36 and offshore zone-Stn. 100.

\begin{tabular}{cccc}
\hline Month & Fish Species & Minima (SD) & Maxima (SD) \\
\hline 1 & TV, TZ, TN & $0.41(0.24)$ & $1.62(1.18)$ \\
2 & TV, TN & $0.54(0.29)$ & $1.8(0.92)$ \\
3 & TZ, TN, TV, TE, TL & $0.66(0.32)$ & $1.78(1.69)$ \\
& & Average (SD) $0.55(0.3)$ & Average (SD) $1.73(1.35)$ \\
\hline
\end{tabular}



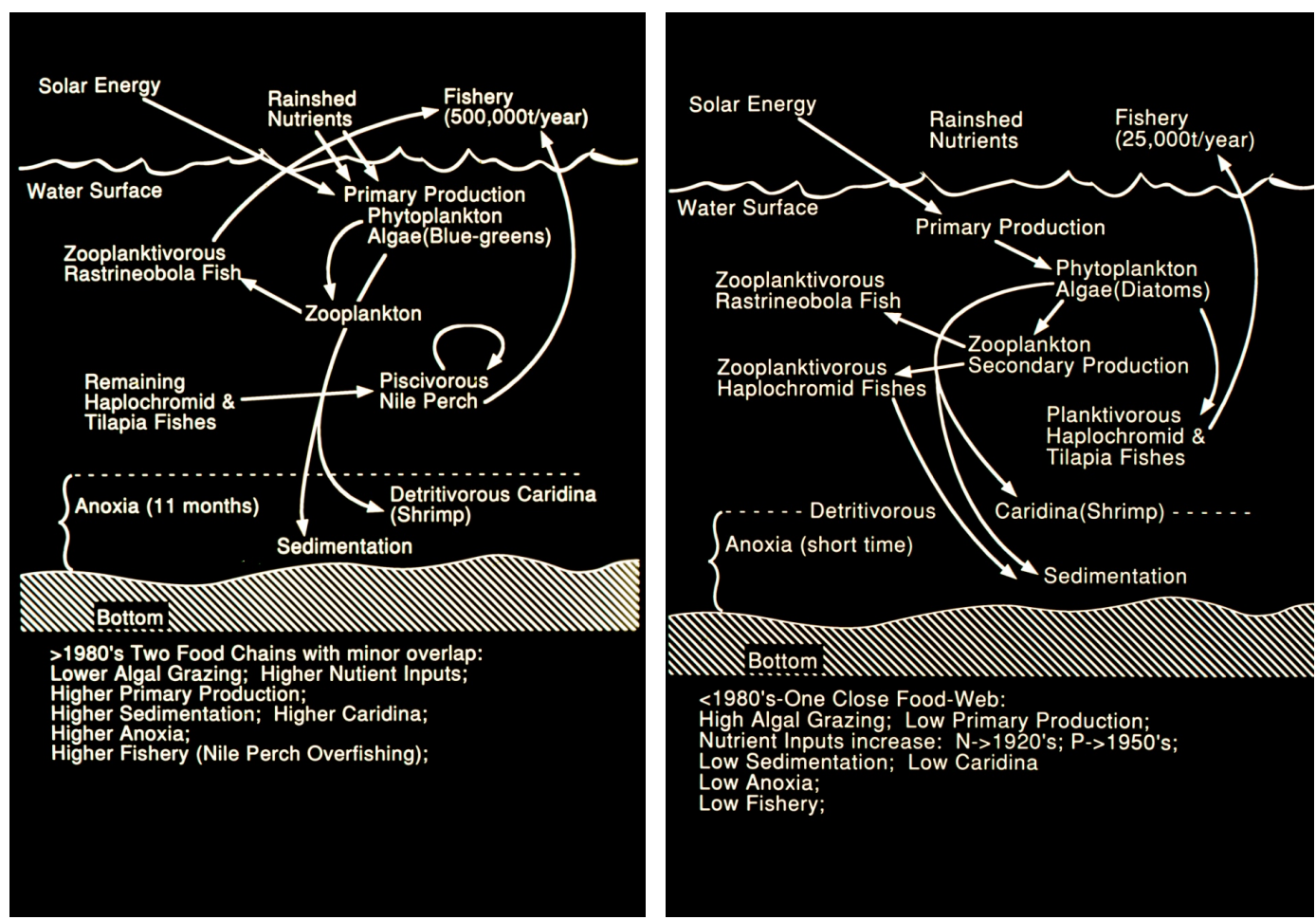

Figure 3. Food-Web structure scheme in Lake Victoria: After 1980 (left) and before 1980 (right) (by courtesy of S.L. Kaufman).

Table 7. Numbers represent $\%$ of fishes contained the indicated food item as dominant ( $>30 \%$ by biomass).

\begin{tabular}{cccc}
\hline Food Item & TZ & TV & TN \\
\hline Plantonic & & 7 & 7 \\
Caridina & 23 & 25 & 28 \\
Phytoplankton & 20 & & 20 \\
Zooplankton & & 26 & 15 \\
Bottom & 21 & 20 & 10 \\
Trichoptera (larvae) & 36 & 12 & 13 \\
Plant Debris & & 10 & 7 \\
Mud \& Sand Grains & & & \\
Bottom Dwellers & & 26 & \\
\hline
\end{tabular}

grazing activity by planktivorous Haplochromines [17] [18] low levels of algal biomass and consequently Primary Production. no surplus of organic matter, low sedimentation and low level of anoxia. Nevertheless an increase of pollutants input was indicated: N-after 1920 and P-after 1950. Low annual fish catches mostly comprised of small size Haplochromines and overfishing avoidance.

After 1980 (Figure 3): Food web structure exhibit disequilibrium. Grazing level decline due to elimination of grazer Haplochromines and dominance of the predator Nile Perch; Therefore, Increase of non-grazed algal biomass (chlorophyll elevation) followed by higher Primary Production accompanied by accumulation of surplus organic matter and sedimentation resulted in enhanced anoxia. Secchi depth and the thickness of the euphotic zone became shallower as a result of higher densities of suspended matter and decline of light penetration [19]-[21]. Decline of available Silica and SRP (Soluble Reactive Phosphorus), and the decline of TN/TP mass 
ratio were probably the reason for the replacement of Diatom before 1980 by Cyanobacteria dominance after 1980 (Table 8). Another outcome of those changes was the proliferation of the detritivorous Atyid-Decapod Caridina nilotica. The total annual landings were significantly enhanced as a result of the optimal conditions for the reproduction and growth of the Nile Perch. The ecological structure modification summarized here gave scientists and managers the basis for further programming fisheries activity. Recent information does not confirm significant improvement in comparison with data presented in this paper.

Cyanobacteria replaced Diatoms, Secchi Depth became shallower, i.e. turbidity enhancement, the euphotic zone became thinner due to increase of turbidity and decline of light penetration, increase of algal density accompanied by elevation of primary production and organic matter content which caused increase of anoxia. Moreover, computation of total lake primary production (annual tons Carbon entire lake assimilation) indicated an increase from $1.7 \times 10^{7}$ during the 1960's to $10.5 \times 10^{7}$ during the 1990's [19]-[21]. Fish landings increased from 25,000 tons to 500,000 tons during the 1960 's and 1990 's respectively. Consequently \% of fish catches relative to Primary Production was increased from $0.01 \%$ to $0.05 \%$ and the depth of the thermocline became shallower by 30 meters (from 60 to $30 \mathrm{~m}$ ) [19]-[21]. The food Web pattern of energy flow was prominently modified and Lake Victoria before the 1980's is different from that established after the 1980's (Figure 3). Figures 3-5 represent clearly the changes which enhanced those modifications of the food web structure. The

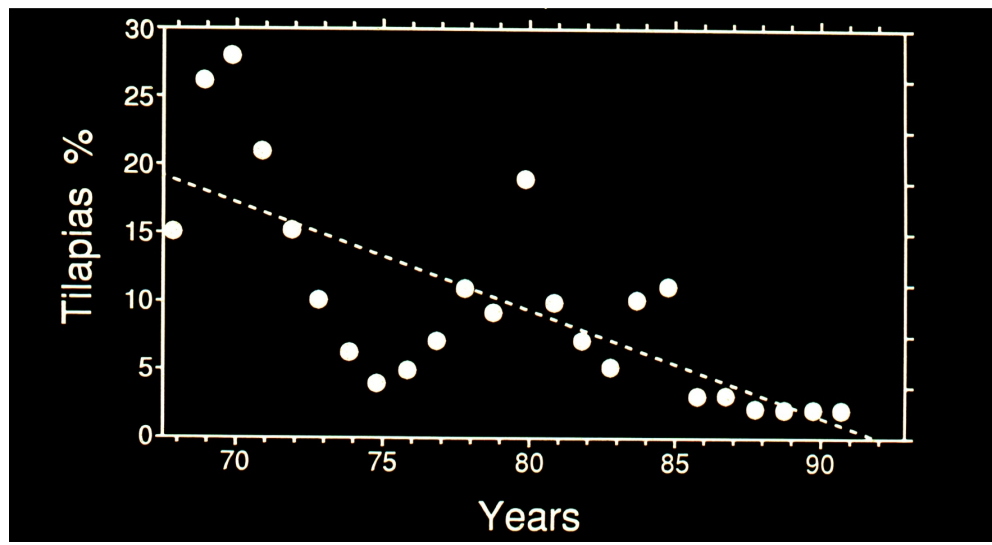

Figure 4. Percentage of Kenya Tilapias annual catches from total landings Vs years (1968-1992). R-Squared $=0.524 ; \mathrm{p}=0.0001$. (Data souece: Kenya Marine and Fisheries Research Institute).

Table 8. Comparative data from Lake Victoria: 1960-Uganda-Talling [4] [5]; Uganda-1990-[20] [21] Kenya 1990-Gophen this paper (statistical evaluation of [4] [5], and [20] [21] are given in those articles.

\begin{tabular}{|c|c|c|c|}
\hline Parameter & Uganda 1960 & Uganda 1990 & Kenya 1990 \\
\hline $\mathrm{NH}_{4}$ (ppm: Epil. Hypol.) & & $0.0280 .056-0.12$ & $0.008-0.0130 .021-0.152$ \\
\hline $\mathrm{NO}_{3}(\mathrm{ppm})$ & $0.00-0.01$ & $0.011-0.084$ & $0.01-0.03$ \\
\hline SRP (ppm) & $0.091-0.50$ & $0.012-0.043$ & $0.004-0.073$ \\
\hline $\mathrm{TP}(\mathrm{ppm})$ & & $0.062-0.124$ & $0.07-0.103$ \\
\hline TN (ppm) & & $0.336-0.448$ & $0.44-1.16$ \\
\hline TN/TP (Wt/Wt) & & $3.2-9.0$ & $4.7-18.5$ \\
\hline$<4.0 \mathrm{ppm}$ DO Depth (m) & 40 & 23 & 23 \\
\hline Silica (ppm) & $4.2-8.4$ & $0.01-2.5$ & \\
\hline Chlorophyll $(\mu \mathrm{g} / \mathrm{L})$ & $2-4$ & $10-22$ & \\
\hline Primary Production $\left(\mathrm{mgO}_{2} / \mathrm{m}^{3}\right)$ & $100-130$ & $180-600$ & \\
\hline Secchi Depth & 2.5 & 1.2 & 1.8 \\
\hline Euphotic Zone & $0-15$ & $0-7.5$ & \\
\hline Dominant algae & Diatoms & Cyanobacteria & Cyanobacteria \\
\hline
\end{tabular}




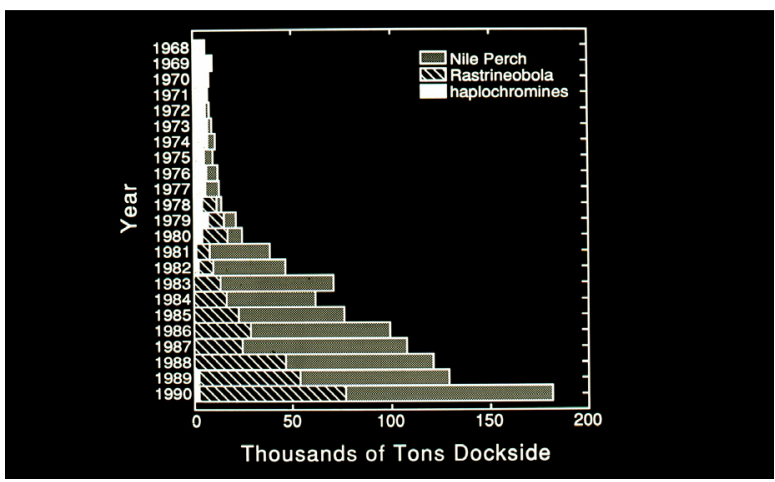

(a)

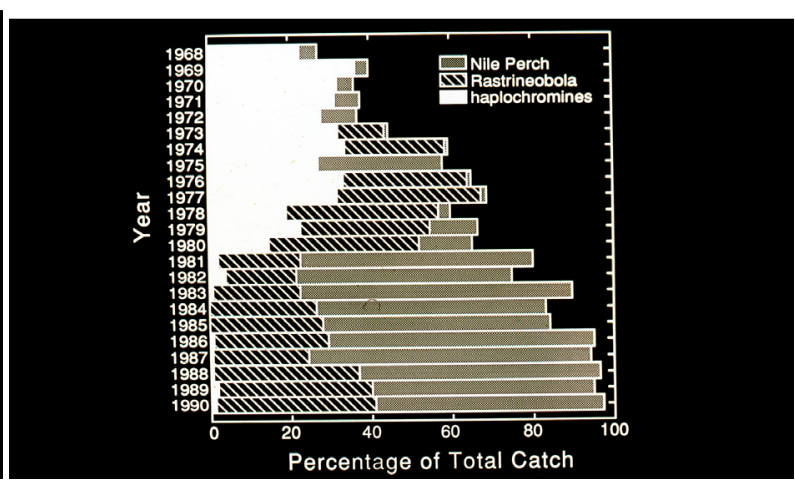

(b)

Figure 5. (a) Kenya annual (1968-1990) Landings (103 tons/year) of Nile Perch, Rastrineobola and Haplochromines. (by courtesy of S.L.Kaufman) Data: Kenya Marine and Fisheries Research Institute; (b) Annual (1968-1990) commercial catch compositions (\%) in Lake Victoria, Kenya. (by courtesy of S.L.Kaufman). Data: Kenya Marine and Fisheries Research Institute.

fish faunal composition was modified from the dominant native Haplochromines which were replaced by the exotic Nile Perch and native Rastrineobobla [22]. Lake Victoria is presently exhibit traditional symptoms of eutrophication: decline of water transparency, Cyanobacteria are dominant, elevation of $\mathrm{P}$ and decline of $\mathrm{N}$ levels, increase of algal biomass (chlorophyll concentration), shallower Secchi depth and thinner euphotic zone and anoxia enhancement. Future management design of fishery in lake Victoria must therefore be done very carefully. Distinct objectives are proposed: 1) reduction of pollutant inputs resulted by anthropogenic activity; 2) increase level of phytoplankton grazing. The second target is difficult due to the intensive predation pressure produced by the Nile Perch. Relevant fish species might be planktivorous large body Tilapias. Tilapias of native and exotic origin are known to be able to survive under the new habitat if may introduce to the lake as large un-preyed individuals. The concept of the Nile Perch predation impact and its ecological implications is also confirmed by the elimination of the Haplochromines's planktivory (Table 4). Nevertheless, the small body size of the Haplochromine fishes make them vulnerable for predation and therefore not suitable for management if aimed at enhancement of planktivory. Large body size of the planktivorous Tilapias are less vulnerable to Nile Perch predation. Index Of Satiation calculated for Tilapias species collected from the natural lake population indicated high values (Table 6) in comparison with the range of 0.5 - 4.0 that was obtained from farm cultured fish given an optimally food quantity [23]. Consequently I assume that the planktivorous capabilities of Tilapias might be beneficial for ecological recovery of Lake Victoria.

\section{Summary}

The Lake Victoria ecosystem was unique included above 400 endemic species of Haplochromine fishes. The food web structure was naturally balanced during that time with short periods of anoxia in deep waters and dominance of diatomides algal species. Nile Perch (Lates niloticus) was introduced and during the 1980's became the dominant fish. The Haplochromine species were deleted and the whole ecosystem was modified. Algal assemblages were changed to Cyanobacteria, anoxia became more frequent and in shallower waters. Primary production was enhanced and excess of organic matter was settled to the bottom. A study of Tilapias feeding habits, zooplankton and Phytoplankton distribution was carried out and results indicates an ecological devastation trait of the ecosystem. Ideas for future management are presented.

\section{Acknowledgements}

I wish to give warm thanks to the Kenyan and American collaborators:

Kenya: E. Okemwa, J. Ogari, S. Agembe, E. Odada, W. Owieko, J. Manyala, J. Ochuko.

USA: L. S. Kaufman, and W. Cooper.

Since this study was completed, three of the principal investigators and major leaders of the research team were deceased: P. B. O. Ochumba, U. Pollingher and P. Kilham. Without their contribution, the study could not be accomplished. I dedicate this paper to their unforgettable remembered collaborative personality and scientific 
skillful.

\section{References}

[1] Barel, C.D.N., Dorit, R., Greenwood, P.H., Fryer, G., Hughes, N., Jackson, P.B.N., Kawanabe, H. and Lowe-McConell, R.H. (1985) Destruction of Fisheries in Africa's Lakes. Nature, 325, 19-20. http://dx.doi.org/10.1038/315019a0

[2] Ochumba, P.B.O., Gophen, M. and Pollingher, U. (1994) Ecological Changes in Lake Victoria after the Introduction of Nile Perch (Lates niloticus): The Catchment, Water Quality and Fisheries Management. In: Cowx, I.G., Ed., Rehabilitation of Freshwater Fisheries, Fishing News Books, Blackwell Scientific Publications Ltd., 338-347.

[3] Gophen, M., Ochumba, P.B.O. and Kaufman, L.S. (1995) Some Aspects of Perturbations in the Structure and Biodiversity of the Ecosystem of Lake Victoria. Aquatic Living Resources, 8, 27-41. http://dx.doi.org/10.1051/alr:1995003

[4] Talling, J.F. (1965) The Pjtosymthetic Cativity of Phtoplankton in East African Lakes. Internationale Revue der gesamten Hydrobiologie und Hydrographie, 50, 1-32. http://dx.doi.org/10.1002/iroh.19650500102

[5] Talling, J.F. (1966) The Annual Cycle of Stratification and Phytoplankton Growth in Lake Victoria (East Africa). Internationale Revue der gesamten Hydrobiologie und Hydrographie, 51, 545-621.

[6] Akiyama, T., Kajumulo, A. and Olsen, S. (1977) Seasonal Variation of Plankton and Physico-Chemical Condition in Mwanza Gulf, Lake Victoria. Bulletin Freshwater Fisheries Research Laboratory, 27, 49-61.

[7] Melack, J.M. (1979) Photosynthetic Rates in Four Tropical African Freshwatrs. Freshwater Biology, 9, 555-571. http://dx.doi.org/10.1111/j.1365-2427.1979.tb01539.x

[8] LBDA (Lake Basin Development Authority) (1984) Technical Report on Current and Future Implications of Development to the Aquatic Environment of Lake Victoria. Wynam Gulf Baseline Study Report, LBDA, Kisumu, 55 p.

[9] Ochumba, P.B.O. and Kibara, D. (1989) Observation on Blue-Green Algal Blooms in the Open Waters of Lak Victoria, Kenya. African Journal of Ecology, 27, 23-34. http://dx.doi.org/10.1111/j.1365-2028.1989.tb00925.x

[10] Rzoska, J. (1956) The Planktonic Crustacea of Lake Victoria. Proceedings of the Linnean Society of London, 168, 116125. http://dx.doi.org/10.1111/j.1095-8312.1957.tb00774_116.x

[11] Rzoska, J. (1957) Notes on the Crustaceans of Lake Victoria. Proceedings of the Linnean Society of London, 168, 116125.

[12] Rzoska, J. (1978) Zooplankton of the Nile System. In: Rzoska, J., Ed., The Nile, Biology of an Ancient River, Dr Junk Publishers, The Hgue, 333-343.

[13] Mavuti, K.M. and Litterick, M.R. (1991) Composition, Distribution and Ecological Role of Zooplankton Community in Lake Victoria, Kenia Waters. Verhandlungen des Internationalen Verein Limnologie, 24, 1117-1122.

[14] Green, J. (1971) Association of Cladocera in the Zooplankton of the Lake Sources of the White Nile. Journal of Zoology, 165, 373-414. http://dx.doi.org/10.1111/j.1469-7998.1971.tb02195.x

[15] Fryer, G. and Iles, T.D. (1972) The Cichlid Fishes of the Great Lakes of Africa: Their Biology and Evolution. Oliver and Boyd, Edinburgh, 641 p.

[16] Kaufman, L.S. (1991) The Anatomy of Vertebrate Mass Extinction as Revealed by a Faunal Survey of Lake Victoria. Annual Report, New England Aquarium, Boston, 51 p.

[17] Greenwood, P.H. (1974) The Haplochromine Fishes of Lake Victoria, East Africa: The Biology and Evolution of a Species Flock. Bulletin of the British Museum of Natural History Zoology, 6, 1-134.

[18] Greenwood, P.H. (1981) The Haplochromine Fishes of East African Lakes: Taxonomy, Biology and Evolution. Kraus International Publications, Munich, 839 p.

[19] Silsbe, G.M., Hecky, R.E., Guildford, S.J. and Mugidde, R. (2006) Variability of Chlorophyll A and Photosynthetic Parameters in a Nutrient-Saturated Tropical Great Lake. Limnology and Oceanography, 51, 2052-2063. http://dx.doi.org/10.4319/lo.2006.51.5.2052

[20] Kling, H.J., Mugidde, R. and Hecky, R.E. (2001) Recent Changes in the Phytoplankton Community of Lake Victoria in Response to Eutrophication. In: Munawar, M. and Hecky, R.E., Eds., The Great Lakes of the World (GLOW): Food Web, Health and Integrity, Backhuys Publishers, Leiden, 47-65.

[21] Hecky, R.E., Mugidde, R., Ramlal, P.S., Talbot, M.R. and Kling, G.W. (2010) Multiple Stressors Cause Rapid Ecosystem Change in Lake Victoria. Freshwater Biology, 55, 19-42. http://dx.doi.org/10.1111/j.1365-2427.2009.02374.x

[22] Kaufman, L.S. (1992) Catastrophic Change in Species-Rich Freshwater Ecosystems: The Lesson of Lake Victoria. BioScience, 42, 846-858. http://dx.doi.org/10.2307/1312084

[23] Shi, Z.F., Liu, Z.Y., Li, J.L. and Mei, Z.P. (1997) Effects of Dissolved Oxygen on the Feeding Intensity of Silver Carp (H. molitrix), and Bighead Carp (A. nobilis). In: Mathias, J.A., Charles, A.T. and Baotong, H., Eds., Proceedings of a Workshop on Integrated Fish Farming, CRC Press, LLC, Boca Raton, 205-212. 